\title{
Rekurrens glioblastomában szenvedő betegek kezelése bevacizumab-monoterápiával
}

\author{
Sinkó Dániel dr. - Nemeskéri Csaba dr. \\ Uzsoki Utcai Kórház, Semmelweis Egyetem Oktató Kórháza, Fővárosi Onkoradiológiai Központ, Budapest
}

\begin{abstract}
Bevezetés: A rekurrens glioblastoma multiforme prognózisa igen rossz, az átlagos túlélés nem haladja meg a 6 hónapot. Célkitüzés: Jelen vizsgálat célja, hogy a szerzők értékeljék a saját gyakorlatukban előforduló rekurráló glioblastomás betegeken a bevacizumab-monoterápia hatékonyságát. Módszer: 2012 áprilisa és 2015 júniusa között 40 betegnél történt bevacizumabkezelés rekurráló glioblastoma miatt, kéthetenként $10 \mathrm{mg} / \mathrm{kg}$ dózissal. Eredmények: Az átlagos progressziómentes túlélés 6,4 hónap (2-22 hónap), a 6 hónapos progressziómentes túlélés $42,5 \%$ volt. A 6 hónapos teljes túlélés 82,5\%-nak bizonyult, ami megfelel a nemzetközi irodalomban közölt adatoknak. Következtetések: A bevacizumab-monoterápia javítja a progressziómentes túlélést rekurráló glioblastomás betegekben. Orv. Hetil., $2016,157(13), 500-503$.
\end{abstract}

Kulcsszavak: glioblastoma multiforme, bevacizumab, progressziómentes túlélés

\section{Treatment of recurrent glioblastoma with single-agent bevacizumab}

Introduction: The prognosis of patients with recurrent glioblastoma is poor, as the median survival does not exceed 6 months. Aim: The aim of this study was to evaluate the efficacy of bevacizumab monotherapy in patients with recurrent glioblastoma multiforme. Method: From April, 2012 to June, 2015, 40 patients with recurrent glioblastoma multiforme were treated with bevacizumab in a dose of $10 \mathrm{mg} / \mathrm{kg}$ every 2 weeks. Results: The average progressionfree survival was 6.4 months (2-22 months), and the 6-month progression-free survival was $42.5 \%$. The six-month overall survival was $82.5 \%$, which corresponds to those published in the literature. Conclusions: Bevacizumab monotherapy improves progression-free survival in patients with recurrent glioblastoma multiforme.

Keywords: glioblastoma multiforme, bevacizumab, progression-free survival

Sinkó, D., Nemeskéri, Cs. [Treatment of recurrent glioblastoma with single-agent bevacizumab]. Orv. Hetil., 2016, 157(13), 500-503.

(Beérkezett: 2016. január 14.; elfogadva: 2016. február 9.)

\section{Rövidítések}

3D konformális sugárkezelés = CT-alapon tervezett háromdimenziós alakhü besugárzás; BCNU = carmustin; $\mathrm{CCNU}=$ komustin; FDA = Food and Drug Administration; IDH = izocitrát-dehidrogenáz; MGMT = O-6-metilguanin-metiltranszferáz; $\mathrm{NCCN}=$ National Comprehensive Cancer Network; PCV = procarbazin, lomustin és vincristin kemoterápia; $\mathrm{RPA}=\mathrm{Re}$ cursive Partitioning Analysis; VEGF = vascular endothelial growth factor
Az elsődleges központi idegrendszeri daganatok a ritkább onkológiai megbetegedések közé tartoznak, az öszszes daganatos betegség kevesebb mint 2\%-át alkotják. Ennek nagyobb része, körülbelül 60\%-a neuroepithelialis daganat. A Nemzeti Rákregiszter adati szerint 2013-ban 1883 elsődleges agydaganatot regisztráltak Magyarországon, közel azonos arányban férfiaknál és a nóknél [1]. Ebből nagyjából 600-700 esetben fordul elő glioblasto- 
ma multiforme, WHO Grade IV, de erról egészen pontos adat nem áll rendelkezésre, ez inkább a szakirodalom alapján becsült érték.

A glioblastoma multiforme kezelése az elmúlt években változáson ment keresztül. Továbbra is a kezelés gerincét a jó radikalitással elvégzett mútét és a 3D konformális sugárkezelés adja, de az elmúlt években a citosztatikus kezelés területén is fejlődés történt. Az első nagy áttörést a radiokemoterápia során bevezetett, majd adjuváns céllal adott temozolomid jelentette.

Stupp és mtsai által publikált közleményben először 2005-ben, majd frissített, nagy betegszámú adatokkal 2009-ben igazolták, hogy a radiokemoterápia, majd adjuváns temozolomidkezelés a hároméves túlélést 4,4\%ról 16\%-ra, az 5 éves túlélést 1,9\%-ról 9,8\%-ra növelte [2, 3]. A glioblastoma multiforme "gold standard terápiája" a mútéti ellátás, majd radiokemoterápia és adjuváns temozolomidkezelés lett, amely randomizált fázis III vizsgálatok alapján l-es szintű ajánlás (NCCN - Categories of Evidence and Consensus).

A vizsgálatok további analízise rámutatott arra, hogy a glioblastoma multiforme nem homogén betegcsoport, prognózis szempontjából fontos szövettani altípusok jelennek meg, például az izocitrát-dehidrogenáz (IDH) -mutáció státuszának, az O-6-metilguanin-metiltranszferáz (MGMT) -metiláció vagy $\mathrm{lp} / 19 \mathrm{q}$ codeletio státuszának függvényében.

A hagyományos kemoterápiás szerek fóként rekurráló high grade glioma vagy glioblastoma multiforme esetében jönnek szóba, de a nitrozoureaszármazékok, a procarbazin, lomustin és vincristin (PCV), carmustin (BCNU) vagy a platinabázisú kemoterápiák szerény eredményt nyújtanak, 2B ajánlási kategóriába tartoznak $[4,5]$.

Leginkább a hagyományos kemoterápiák sikertelensége miatt intenzív vizsgálatok folytak célzott biológiai kezelésekkel. Tekintettel arra, hogy a glioblastoma igen gazdag vérellátással bír, logikus célpontnak tûnt az angiogenezis gátlása monoklonális antitesttel. A vascular endothelial growth factort (VEGF-) gátlók csoportjába tartozó bevacizumabot 2009-ben hagyta jóvá gyorsított eljárással az FDA (Food and Drug Administration) rekurrens glioblastoma indikációban. A törzskönyvezés 2 publikáció alapján történt, aminek érdekessége, hogy a leközölt eredmények nem randomizált, placebokontrollos vizsgálatok voltak. Kontroll- vagy placebokar nélkül minden vizsgálatban részt vevő beteg kapott bevacizumabot, ráadásul az egyik vizsgálatba csak 35 beteget válogattak be $[6,7]$. Ez az oka annak, hogy egészen pontosan nincs információ arról, hogy a bevacizumab ténylegesen mennyi előnyt jelent a progressziómentes túlélésben vagy a teljes túlélésben. Az említett vizsgálatok során legtöbb esetben irinotecan kombinációs vagy bevacizumab-monoterápia történt, amely szintén heterogénné tette a betegpopulációt és nehezítette a további összehasonlítás lehetőségét [8].
A 23 ország részvételével lefolytatott AVAglio vizsgálat nagyrészt tisztázta a bevacizumab szerepét a glioblastoma primer terápiájában. A 2014-ben lezárult vizsgálat szerint temozolomidalapú radiokemoterápia mellé adva a bevacizumab javítja a progressziómentes túlélést $(6,2$ hónapról 10,6 hónapra), de a teljes túlélésre nincs hatással. Kiemelendő, hogy az életminőség lényegesen jobb volt a bevacizumabkaron, valamint a betegek jóval kevesebb kortikoszteroidmedikációra kényszerültek [9]. 2015-ben publikált fázis III randomizált vizsgálat szerint viszont a progressziómentes időszakban az életminőségre nincs egyértelmú hatással a bevacizumab [10].

A vizsgálatok a bevacizumab és szinkrón radiokemoterápia előnyeit igazolták, de továbbra is kérdéses a bevacizumab szerepe a rekurráló glioblastoma kezelésében, valamint a pontos dozírozás, a betegszelekció kérdése, és a kezelések időtartamának meghatározása is várat magára [11].

Tisztázatlan továbbá a monoterápia vagy citotoxikus szerrel való kombináció kérdése is. Leggyakrabban az irinotecan/bevacizumab kombináció terjedt el, amely a teljes túlélésben akár elónyt is jelenthet, de újabb tanulmányok (például a BELOB vizsgálat) jelentek meg bevacizumab/CCNU kombinációról rekurráló glioblastomás betegek esetében, ahol a hozzáadott CCNU egyértelmúen javította mind a progressziómentes túlélést, mind a teljes túlélést [12-14].

Kombinált kezelések során lényegesen változik a mellékhatásprofil, de önmagában adott bevacizumab jól tolerálható, biztonságos, leginkább hypertonia és proteinuria jelentkezik, amelyek hosszú távon az esetek nagyobb részében egyensúlyban tarthatók [15].

\section{Betegek és módszer}

2012. április 13. és 2015. június 20. között 50 betegnél adtunk be egyedi méltányossági kérelmet rekurráló glioblastoma indikációban bevacizumab (Avastin) -kezelés elbírálására. A betegek mindegyikénél történ mútét vagy szövettani mintavétel, sugárkezelés (radiokemoterápia) és temozolomidkezelés.

50 betegból 40 beteg primer glioblastomás és 10 beteg transzformálódott, szekunder glioblastomás volt. Szekunder glioblastomás betegnél mind a progressziómentes túlélést, mind a teljes túlélést a glioblastoma multiforme szövettan igazolásától számoltuk. MR-vizsgálattal igazolt progresszió mellett, oncoteam döntése után kezdeményeztük a bevacizumabkezelést. A betegek Karnofsky performance statusa 60-100 között volt, RPA-klasszifikáció szerint III-V. szint (RPA: Recursive Partitioning Analysis). Az egyedi méltányossági kérelem elbírálása átlag 6 hetet vett igénybe (3-12 hét). Az átlagos követési idő 14 hónap volt (6-22 hónap). A bevacizumab dózisa $10 \mathrm{mg} / \mathrm{kg}$ volt kéthetenként radiológiai vagy klinikai progresszióig. Képalkotó kontrollvizsgálatok 90 naponként történtek. 
Állapotromlás miatt 50 betegből 10 betegnél nem tudtuk a kezelést megkezdeni, ezért 40 beteg adatai kerültek végül feldolgozásra $(80 \%)$. Abból a 10 betegből, aki már nem volt alkalmas a kezelés megkezdésére, 4 beteg státusza az adminisztráció elindításakor KPS 70 vagy a felett volt, és 6 betegnél volt a performance status 60 körül. Az egész vizsgálati csoportban, vagyis a kezelést megkapó és kezelésre nem alkalmas betegek között összesen nyolc esetben volt a KPS 60 körül. Ezek közül 6 esetben nem tudtuk a már jóváhagyott kezelést megkezdeni, de a maradék 2 esetben sikerrel megkezdtük, majd folytatni is tudtuk a terápiát.

\section{Eredmények}

A progressziómentes túlélés 40 beteg esetében 6,43 hónap (2-22 hónap) volt. A betegek 42,5\%-a (17/40) élt hat hónapon túl progresszió nélkül. A hat hónapos teljes túlélés a bevacizumabkezelés alatt $82,5 \%$-nak bizonyult $(33 / 40)$ (1. táblázat).

1. táblázat |A kezelés eredményei

\begin{tabular}{ll}
\hline Betegszám & $\mathrm{N}=40$ \\
6 hónapos progressziómentes túlélés & $42,5 \%$ \\
6 hónapos teljes túlélés & $82,5 \%$ \\
Átlagos progressziómentes túlélés & 6,4 hónap \\
Átlagos teljes túlélés & 21,7 hónap \\
\hline
\end{tabular}

Tíz szekunder glioblastomás beteg közül egy esetben nem tudtuk a kezelést elkezdeni, ezért a végleges kiértékelésben 9 eset jelent meg. Szekunder glioblastomások esetében a progressziómentes túlélés 4,55 hónap (2-8 hónap) volt, és a betegek 33,3\%-a (3/9) élt hat hónapon túl.

Egy betegnél a harmadik kezelés után leállítottuk a bevacizumab adását CT-, majd MR-vizsgálattal is igazolt intracranialis vérzés miatt, de a betegnek neurológiai deficitje nem maradt vissza. Egy beteget az onkológiai kezeléstől függetlenül, akut hasi kórkép miatt elvesztettünk. Két betegnél tapasztaltunk proteinuriát, de egyik betegnél sem haladta meg a 24 órás proteinürítés az 1 grammot (grade I proteinuria). A többi kezelés érdemi mellékhatások nélkül lezajlott.

A teljes túlélés mind a primer, mind a szekunder glioblastomás betegeknél 21,7 hónap (4-61 hónap). Itt meg kell jegyezni, hogy a teljes túlélés eredménye mindenképpen tájékozódó jellegú, mert például a bevacizumabkezelés után progrediáló, de jó általános állapotú betegeknél további ellátás is történt lokalizációtól függő́en (reoperáció, reirradiáció, $\mathrm{BCNU}, \mathrm{CCNU}$, temozolomid kemoterápiás kezelés). Ez viszont heterogénné teszi a betegpopulációt és befolyásolja a statisztikai feldolgozás lehetőségét.

\section{Megbeszélés}

Saját eredményeink alapján kimondható, hogy a bevacizumabkezelés több mint hat hónappal megnyújtja a progresszióig eltelt időt, amely eredmények megfelelnek az idevonatkozó szakirodalomban leírtaknak. Egyértelmúen rosszabb prognózissal bírnak a transzformálódott, szekunder glioblastomás betegek, mind a progressziómentes időszak, mind a túlélés vonatkozásában.

A kezelések biztonsággal, alacsony toxicitás mellett kivitelezhetőek, esetünkben számottevő súlyos mellékhatás nélkül le tudtuk bonyolítani őket. Fel kell hívni a figyelmet arra, hogy a progressziómentes időszak átlag hat hónapos értéke igen széles határok között mutatkozott. Két beteg is van, akik több mint 22 hónapja kapják a bevacizumabkezelést és a kontroll-MR-vizsgálatok végig stabil betegséget igazolnak.

Viszonylag nagy arányban, a betegek 20\%-ánál(!) nem tudtuk elkezdeni a már jóváhagyott kezelést. Fontos, hogy e betegek közel felének állapota hamar, néhány héten belül rosszabbodott, és ez idő alatt romlott a performance statusuk. Másfelől mindenképpen fontos információt nyertünk azáltal, hogy a kezelések során rosszabb állapotú betegeknél is kezdtünk kezelést (KPS $=60, \mathrm{RPA}$ IV-V.), fóként fiatal betegeknél, mert ebben a csoportban is voltak, akiknél hasznosnak bizonyult a bevacizumabkezelés.

Végül meg kell említeni, hogy a 6 hónapos progreszsziómentes időszakot figyelembe véve az átlag másfél hónap adminisztráció igen nagy jelentőséggel bír, feltételezhető, hogy idejében megkezdett terápia még jobb eredményeket mutatna.

\section{Következtetések}

A bevacizumab monoterápiában biztonsággal adható rekurrens glioblastomás betegeknek. A kezelés egyértelmúen meghosszabbítja a progressziómentes túlélést. Szekunder glioblastomás betegek esetében az eredmények jóval szerényebbek. A progressziómentes túlélés igen széles határok között változik.

Anyagi támogatás: A közlemény megírása anyagi támogatásban nem részesült.

Szerzöi munkamegosztás: S. D.: A vizsgálat lefolytatása, statisztikai elemzések, a kézirat megszövegezése. N. Cs.: A kézirat megszövegezése. A cikk végleges változatát mindkét szerző elolvasta és jóváhagyta.

Érdekeltségek: A szerzőknek nincsenek érdekeltségeik. 


\section{Irodalom}

[1] National Cancer Registry 2013. [Nemzeti Rákregiszter 2013.$]$ http://www.onkol.hu/hu/rakregiszter-statisztika [Hungarian]

[2] Stupp, R., Mason, W. P., van den Bent, M. J., et al.: Radiotherapy plus concomitant and adjuvant temozolomide for glioblastoma. N. Engl. J. Med., 2005, 352(10), 987-996.

[3] Stupp, R., Hegi, M. E., Mason, W. P., et al.: Effects of radiotherapy with concomitant and adjuvant temozolomide versus radiothreapy alone on survival in glioblastoma in a randomised phase III study: 5-year analysis of the EORTC-NCIC trial. Lancet Oncol., 2009, 10(5), 459-466.

[4] National Comprehensive Cancer Network Guidelines for Central Nervous System Cancers. 2015 NCCN. Version 1.2015 http://www.nccn.org/professionals

[5] Triebels, V. H., Taphoorn, M. J., Brandes, A. A, et al.: Salvage PCV chemotherapy for temozolomide-resistant oligodendrogliomas. Neurology, 2004, 63(5), 904-906.

[6] Friedman, H. S., Prados, M. D., Wen, P. Y., et al.: Bevacizumab alone and in combination with irinotecan in recurrent glioblastoma. J. Clin. Oncol., 2009, 27(28), 4733-4740.

[7] Vredenburgh, J. J., Desjardins, A., Herndon, J. E. 2nd, et al.: Bevacizumab plus irinotecan in recurrent glioblastoma multiforme. J. Clin. Oncol., 2007, 25(30), 4722-4729.

[8] Kreisl, T. N., Kim, L., Moore, K., et al.: Phase II trial of singleagent bevacizumab followed by bevacizumab plus irinotecan at tumor progression in recurrent glioblastoma. J. Clin. Oncol., $2009,27(5), 740-745$
[9] Chinot, O. L., Wick, W., Mason, W., et al.: Bevacizumab plus radiotherapy-temozolomide for newly diagnosed glioblastoma. N. Engl. J. Med., 2014, 370(8), 709-722.

[10] Taphoorn, M. J., Henriksson, R., Bottomley, A., et al.: Health-related quality of life in a randomized phase III study of bevacizumab, temozolomide, and radiotherapy in newly diagnosed glioblastoma. J. Clin. Oncol., 2015, 33(19), 2166-2175.

[11] Chamberlain, M. C.: Bevacizumab for the treatment of recurrent glioblastoma. Clin. Med. Insights Oncol., 2011, 5, 117-129.

[12] Taal, W., Oosterkamp, H. M., Walenkamp, A. M., et al.: Singleagent bevacizumab or lomustine versus a combination of bevacizumab plus lomustine in patients with recurrent glioblastoma (BELOB trial): a randomised controlled phase 2 trial. Lancet Oncol., 2014, 15(9), 943-953.

[13] Blumenthal, D. T., Mendel, L., Bokstein, F.: The optimal regimen of bevacizumab for recurrent glioblastoma: does dose matter? J. Neurooncol., 2015 Dec 31. [Epub ahead of print]

[14] Heiland, D. H., Masalha, W., Franco, P., et al.: Progression-free and overall survival in patients with recurrent glioblastoma multiforme treated with last-line bevacizumab versus bevacizumab/ lomustine. J. Neurooncol., 2016, 126(3), 567-575.

[15] Narita, Y.: Bevacizumab for glioblastoma. Ther. Clin. Risk Manag., 2015, 11, 1759-1765.

(Sinkó Dániel dr., Budapest, Uzsoki u. 29., 1149 e-mail: sinkodaniel@yahoo.com)

\section{A rendezvények és kongresszusok híranyagának leadása}

a lap megjelenése előtt legalább 40 nappal lehetséges, a 6 hetes nyomdai átfutás miatt. Kérjük megrendelőink szíves megértését.

A híranyagokat a következő címre kérjük:

Orvosi Hetilap titkársága: Budai.Edit@akkrt.hu

Akadémiai Kiadó Zrt. 